\title{
Citizen Journalism Training to Strengthen the Role of Youth in Overseeing the Village Development
}

\author{
Rahmad Hidayat ${ }^{1 *}$, Tauhid ${ }^{1}$, Muhammad Sauki ${ }^{2}$ \\ ${ }^{1}$ Department of Administrative Science, STISIP Mbojo, Bima, Indonesia \\ ${ }^{2}$ Department of Communication, STISIP Mbojo, Bima, Indonesia
}

Submitted: January $1^{\text {st }}$ 2020; Revised: Juny $7^{\text {th }} 2021$; Accepted: November $23^{\text {rd }} 2021$

Keywords:

Accountability

Development

Journalism

Supervision

Youth

\begin{abstract}
This training focuses on testing the effectiveness of citizen journalism as a variant of social engineering for the realization of social accountability in managing village development. The potential and active participation of the youth in overseeing the management of village development needs to be sharpened or strengthened through training in the use of media and communication tools. The role of youth must be maximized in a more positive direction in the framework of village policy so they can contribute significantly to improve the pattern of village development management which will significantly influence the acceleration of public welfare achievement. Citizen journalism as a special variant of social engineering must be tested for its relevance and be further developed as an instrument for the realization of social accountability in the village that requires the community to play the role of supervisor for all village government actions. It is conducted by publishing photo-voice narratives in various available communication channels in the village, both in printed and electronic forms. This activity has been carried out for four months in 2019 (August-November) through two learning phases which are classroom learning and mentoring for transferring basic knowledge and reviewing everything that intersects with prospects, constraints and substantive needs of this citizen journalism intervention. Methods used in the training included lectures, discussions, photo-film displays, simulation, presentations, and mentoring. This intervention was effective to increase the youth's knowledge and skill about producing various items of citizen journalism to disseminate substantive information to the public as well as to forge their courage to have a direct dialogue with the village government apparatus regarding important issues that have not been included in the formulation of village development programs.
\end{abstract}

\section{INTRODUCTION}

Youth of Rabakodo Village (Woha Subdistrict, Bima District, West Nusa Tenggara Province) as the target audience in this citizen journalism training was chosen not to galvanize them to be economically productive, but to strengthen their role in monitoring the village development process by optimizing the function of expression space for the actualization of social accountability, namely the implementation of village governance and development by the Village Government and the Consultative Agency (Badan
Permusyawaratan Desa/BPD) in transparent and accountable manners.

Law No. 6/2014 on Villages mandates the realization of a professional, efficient and effective, open and accountable government. While on the community side, this law aims to encourage community initiatives, movements and participation to develop village potentials as well as assets to realize shared prosperity. Both of these objectives require the preconditions for a dynamic relationship between responsive government and active community (Hidayat et al., 2019).

ISSN 2460-9447 (print), ISSN 2541-5883 (online)

${ }^{*}$ Corresponding author : Rahmad Hidayat

Department of Administrative Science, STISIP Mbojo, Jl. Piere Tendean, Mande, Bima, Nusa Tenggara Barat 84115, Indonesia Email: rahidsmart@gmail.com 
The Village Law is framed as a participatory and accommodative regulation of the people's interests. Its spirit is to encourage democratization in decisionmaking, village independence, and development consolidation. The actualization of transparent and accountable village development management is not only focused on the initiatives, roles and actions of the village administration (village government and BPD) but also requires the presence of active citizens who participate in managing village development while overseeing the performance of the village government. In addition, villagers can also use citizen journalism as an informal media channel to engage in regular citizenship forums such as Village Deliberations (Musyawarah Desa/Musdes) and Village Development Planning Deliberations (Musyawarah Perencanaan Pembangunan Desa/Musrenbangdes). They can do it to oversee village development management conducted by the Village Government and BPD.

The social accountability issue of Rabakodo Village Government in managing village development is significant as a basis for conducting this training. It is based on the findings of a preliminary study we did earlier to justify why the citizen journalism approach needs to be applied through community service programs. It happens because some sad realities reflect the "bad performance of the social accountability" of the village government in managing the development processes in the form of (a) the stages of planning, budgeting, and implementation of village development are entirely within the control of the Village Head, where the practices of village governance are colored by the role dysfunction of the apparatus and village institutions to the extent of the practice of extortion by village officials; (b) access to information is very inadequate because certain information can only be accessed by people closest to the village officials, not villagers in general; (c) communication media are still limited to existing formal forums (such as the Musrenbangdes) and, not all elements of the community cannot be involved in it, for example, groups of poor people and women have never been invited to the Musrenbangdes and other regular citizenship forums; (d) no communication media is actively functioning by the Village Government to publicize village development programs and/or communication media that facilitate the needs of citizens regarding budget information for certain development activities or programs. This illustrates the unwillingness of the Village Government to be transparent in delivering village budgeting information.

Based on these heartbreaking facts, it can be concluded that the practice of managing village development in Rabakodo Village is still far from the principles of social accountability and inclusion. Our community service program puts citizen journalism as a special variant of social engineering that must be tested for relevance and further developed as an instrument for the realization of social accountability. It is applied in the village that requires the community to play the role of supervisor for the actions of the Village Government and the $B P D$ through the publication of photo-voice news narratives in various available communication channels in the village, both in printed and electronic forms. Social accountability becomes the basic foundation to unravel the relationship problems between the village administration and the community. Therefore, the engineering of social accountability through citizen journalism intends to build a collective agreement where the village government must be jointly accountable in priority activities, locations, beneficiaries, and budget amount. They have to take care of the common affairs and interests through the allocation of village resources that it holds.

In the current context, the content, reviews, or narratives of various "well-established" journalism products such as newspapers, magazines, tabloids, radio, television, and various online-based publications are unable to represent the interests of all segments of society that become the subject of their reporting. The desire of community members whose interests are left behind or not brought up to the surface by the established journalism product is the origin of the development of citizen journalism. This particular journalism category portrays the existence of certain elements of citizens (not professional journalists) who conduct journalistic activities such as collecting empirical facts, processing them into news, and spreading them to the public.

Citizen journalism initially took simple forms and activities (how citizens independently send news, photos and videos to industrial media). However, in the latest development, citizens began to initiate their publishing by taking various forms of media: websites (blogs), television, radio, and printed media that reach both unlimited and limited communities.

Citizen journalism does not only promotes the perspective of ordinary citizens, but it also helps citizens educate themselves about the cultural and political system, builds social relations, directs public space, and plays a critical role as the supervisor (Rai, 2016). The idea behind citizen journalism is the opportunity for people without professional training in journalism in using modern technology tools and the internet's unlimited reach to raise issues that have never been revealed, because this type of journalism goes beyond the scope of professional journalism. Citizen journalism is the act of a person or group of citizens who involve themselves in the gathering process, reporting, analysis, and dissemination of news and other forms of information. This type of action aims to 
provide relevant, independent and broad information that is crucial to a democratic society (Barnes, 2012).

Furthermore, Banda (2010) has revealed the characteristics and effects of citizen journalism on the values and processes of democracy in the context of the African Continent. Based on exploratory studies, Banda sought to assess how information and communication technology projects, both institutional and noninstitutional, shaped the practice of citizen journalism. Respondents 'perception or understanding of how citizen journalism advances aspects of democratic citizenship (democratic citizenship) in the form of ownership of communication channels, civic participation, power to uphold transparency and accountability of public officials, access and accessibility, deliberation among citizens, decision making or citizens' actions (such as voting as a result of debate), as well as interactivity are positioned as the research locus.

A study on the use of citizen journalism publications through participatory videos and blogs has also been done by Singh (2008). This study uncovers the potential or usefulness of both communication tools or media utilized by Panchayat's women leaders in Bihar-India to encourage their existence to be felt, heard, seen, and publicly recognized. Singh's research presents a detailed process of using videos and blogs by Panchayat's female leaders to document facts, store, process, then produce it again so that local political conditions can be pushed to the accountable and transparent direction.

Bearing this critical role, citizen journalism is not enough to be seen merely as a process of reporting and writing news, publishing journalistic works, and distributing them. It occupies an important space in the critical education process, providing new awareness about who must make changes and criticize the decision-making system at the various levels. Citizen journalism can also foster citizen awareness of the root causes of community suffering caused by social structure errors that are built and enforced based on totally unjust gender values, ignoring the existence of marginal groups in the village, and the grip of reason oriented the interests of money.

Citizen journalism which is positioned as a form of social engineering in our activities is a reflection of villagers' voices, aspirations, complaints, and expressions about their priority needs. Citizens' journalism skills need to be introduced to villagers through special training so that the relevance or even effectiveness of the implementation of accountable village development management can be mapped as a whole. In addition to formal citizenship forums that can be utilized to oversee the management of development carried out by the village government, this activity also aims to change villagers' awareness about alternative routes,. The optimization of the function of certain spaces by citizens as a place of expression, voice, complaints, and information to build two-way communication with village government in the form of dialogue and more substantive interaction between the two is a follow-up effect expected to accompany the achievement of these fundamental outcomes.

The youth group that was asked as the target audience for this activity has been equipped with citizen journalism skills. They will practice further through a series of production activities of news-photo, narratives, as well as performance art on crucial issues that are out of the attention of the Village Government and the BPD. Changes in responses, attitudes, or actions of the Rabakodo Village Administration to published crucial issues to be discussed and accommodated into the village planning-budgeting documents are the main indicators of social accountability realization in the village. Intense dialogue, discussion, or negotiations between the village government and citizen journalists on crucial issues related also become the primary reference for accountable village development management.

\section{METHOD}

All stages of skills training media and communication tools (citizen journalism training) will be conducted by prioritizing the participation of youth groups in Rabakodo Village as partners. This activity has been carried out for four months, from August to November 2019. There were two learning phases implemented during the training namely (i) learning in the classroom with young people as village media teams, and (ii) mentoring and assistance, both face-to-face and distance. Through these two stages of learning, participants will get capacity building in the form of knowledge and skills then practice it in a citizen journalism model.

The core activities conducted during the training consisted of (a) social analysis (identification of crucial village problems); and (b) training in the use of media and communication tools in the form of photography, narration, photo-voice combination, and performance art. Based on these core activities, the types of quantifiable outputs that will be generated can be viewed in the following table:

The types of material that have been delivered in the two stages of learning were (1) perspective-based material, which is expected to be a framework for each participant's practice, in the form of identifying crucial village problems (social analysis), introduction to the main points in Village Planning and Budgeting (Perencanaan-Penganggaran Desa/PPDes), and Public Information Publication; (2) skills-based material, which is expected to be mastered by 
participants from time to time, consisting of photography skills, a compilation of written narratives, creation of art performances based on local traditions, and management of all forms of citizen journalism into interactive media. After learning facilitation (media training and/or communication management in creating strategic media at the village level), the Media Team continues it to the production phase of citizen journalism.

\begin{tabular}{|c|c|c|}
\hline No & Activities & Outputs \\
\hline 1 & Social Analysis & $\begin{array}{l}\text { Participants can identify crucial village } \\
\text { problems that must be addressed } \\
\text { immediately by the Rabakodo Village } \\
\text { Government, especially those relating } \\
\text { to three basic service issues, namely } \\
\text { education, health, and residential } \\
\text { identity. The results of this social } \\
\text { analysis will later function as the main } \\
\text { content of photos, news, photo-news, } \\
\text { and art-tradition performances } \\
\text { produced by the participants. }\end{array}$ \\
\hline 2 & $\begin{array}{l}\text { Training in the } \\
\text { Use of Media and } \\
\text { Communication } \\
\text { Tools }\end{array}$ & $\begin{array}{l}\text { a. Participants understand the } \\
\text { techniques of photography, } \\
\text { narratives or news compilation, } \\
\text { art performances management; } \\
\text { b. Participants master the way to } \\
\text { produce news-photo and art } \\
\text { performances that publish crucial } \\
\text { village issues as their main } \\
\text { content. }\end{array}$ \\
\hline
\end{tabular}

The main approach that was always applied during the training period to identify and discuss everything that intersects with prospects, obstacles, and substantive needs of citizen journalism training consisted of (i) lectures, discussions, and/or brainstorming; (ii) short video playback (photo-film display); (iii) role-play, simulation, or practice (writing news, taking photos) and presentations; and (iv) monitoring \& assistance.

In conjunction with the monitoring and assistance activities, the evaluation step of the implementation team on the implementation of citizen journalism training focused on important matters that have been and could not be understood by the village media team. These important matters include (1) problems or issues, (2) solutions, (3) ) who is most likely to run the solution, and (4) how it can affect those people. This illustrates the importance of focusing on the interests of marginalized groups when planning citizen journalism with social change targets.

\section{RESULT AND DISCUSSION}

\subsection{Socialization of citizen journalism training to the Rabakodo Village government}

The first intervention that was conducted as an inseparable part of the development of citizen journalism in Rabakodo Village was the socialization of media development and communication tools for village planning that was accountable-inclusive to the Village Government and the $B P D$. In this meeting, the facilitators suggested that the Rabakodo Village Government should always open space for community participation in the management of village development. One form of space for participation that can be utilized by the community, outside the regular citizenship forums (such as the Village Deliberation and Village Development Planning Deliberation), is citizen journalism.

The space for community participation in village development planning is not merely through formal and informal activities organized by the Village Government. Space can be created through the development of citizen journalism by citizens themselves. Village Journalists or Media Cadres have significant positions, duties and functions in monitoring the performance of the village government by producing various journalism products such as narration/writing/news, photography, and art performances as the means of channeling the aspirations, interests, or needs of villagers. This is done this way so these aspirations can become a public issue and get the attention of the Village Government, who will subsequently accommodate them in the Village Planning and Budgeting documents.

The availability of access to data and information about village development programs implemented by the Village Government is significant prerequisite for village government accountability. When citizen journalism has been developed, the village government can utilize the presence of these media cadres to disseminate village development matters to the general public. As a result, media cadres can serve as the bridge between people's tongues and the mouthpiece of the village government information. The utilization of citizen journalism must be maximized to avoid conflicts between the village government and residents due to information deadlock.

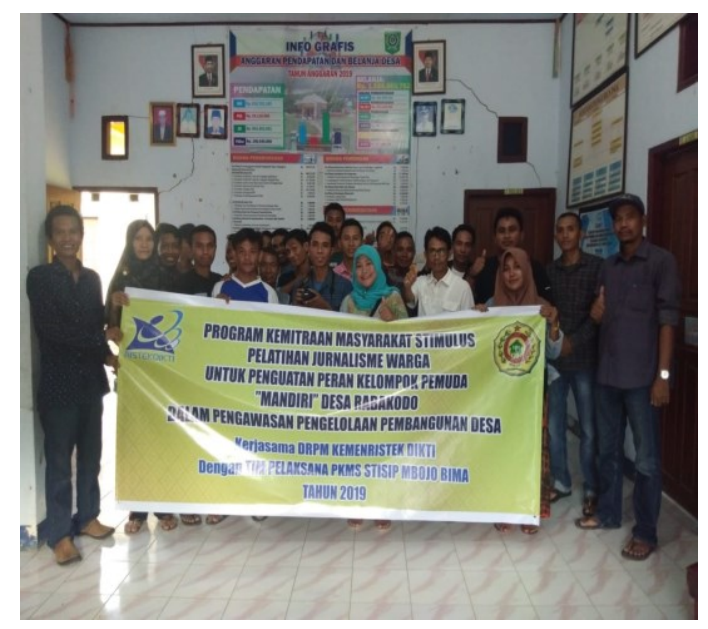

Figure 1. Socialization of citizen journalism training

Citizens who are willing to devote themselves as Village Media Cadres can organize themselves in the Media Teams. The team will handle village media 
management on a regular basis, packaging a variety of complaints, voices and expressions of citizens into journalism products such as news narratives, photography and art performance which are delivered to the general public in the village. Media cadres can work on such products to raise substantive issues about village development that can be a public concern.

\subsection{Introduction and formation of village media}

The activity that specifically involved several youths was oriented toward the introduction and formation of village media. Then, the outline of the "Media Use and Communication Equipment Skills" was mastered by prospective village media cadres. Moreover, this activity has specific objectives as follows: (1) participants understand the learning objectives and have a perspective on strengthening the village through the management of strategic media in the village; (2) participants understand the optimization of the function of spaces that can be used as a forum for expressions, voices, or complaints and information and build two-way communication in the village; (3) participants master the knowledge and skills of all the material delivered by the facilitators; (4) participants make a work team and a strategic plan after co-learning.

In this meeting, the facilitators presented the orientation of Media Training and Communication Tools aimed to educate villagers to become nonprofessional journalists through narratives, photographs, news-photo, and art performances, production about certain crucial issues in Rabakodo Village. The variety of citizen journalism productions is intended to bring certain village issues to the surface, so they can be a public concern and then handled by the Village Government through the village budgetingplanning processes.

During the activity, participants and facilitators interacted with each other on some topics that are briefly discussed within the framework of introducing skills in using tools and communication media. The output is participants' willingness to form village media that can be utilized as a means of disseminating information to the general public in the village. The topic of the discussion consists of (a) village budgeting planning, (b) the citizen communication strategic team, (c) citizen journalism, and (d) public information publication.

\subsection{News narrative writing and photography practices}

In the practical activities of preparing news narratives and photography, the facilitators invited participants to compile news about certain issues or phenomena that were mastered based on their observations and/or experiences. During their presentation, the facilitators explained the position, tasks and functions of Media Cadres on creating various journalism products to channel villagers' needs.

Besides, the facilitators also addressed the substance of Citizen Journalism, which includes the Citizen Communication Strategic Team, Media Cadres and Media Managers. The facilitators delivered more portion of media management, including how Media Cadres can manage complaints, voices, expressions, and news, so they can be used as journalism products to produce news narratives, photography, and/or art performances. The media cadres can select and work on these three items into products that will be produced in pushing issues related to village development. The final presentation will cover how to write news using the 5 $\mathrm{W} 1 \mathrm{H}$ tool as well as determine the theme and angle of the news. After the exposure to these various topics, this activity continued to practice news preparation and taking photos of certain phenomena as support for news content compiled by village media cadres.

\subsection{Advanced practices for making news narratives and photography}

As a follow-up to previous practical activities in preparing news narratives and photography where participants were encouraged to try to compile simple news about certain issues experienced or observed in the village, this activity intends to encourage participants to write news narratives based on the results of field interviews with certain sources.

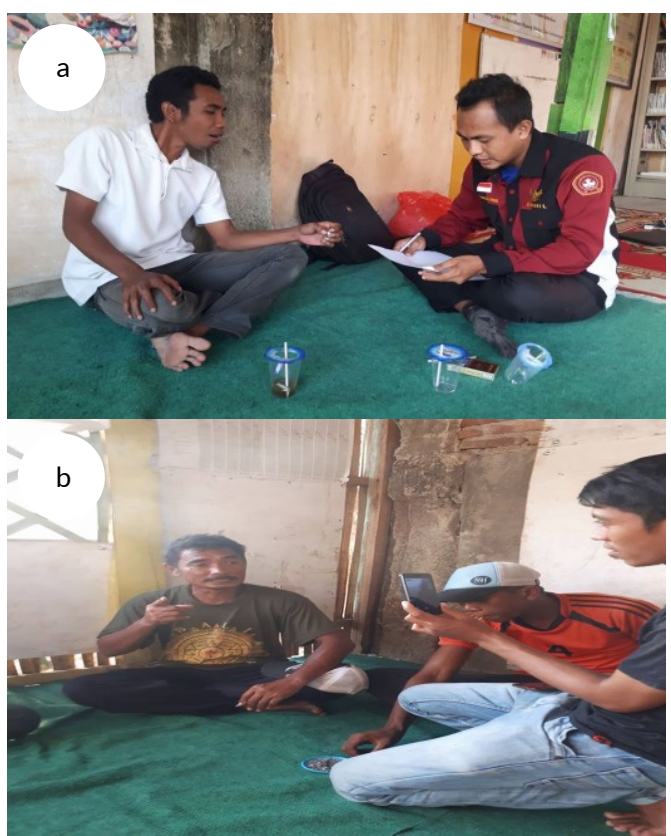

Figure 2. Practices of interview and photo-taking by media cadres a) Simulated interview of a prospective media cadre with the Chairman of the BUMDesa Rabakodo; b) Simulated interview of prospective media cadre with Member of the BPD Rabakodo

In follow-up practice activities, the facilitators invited participants to jointly compiled a news narrative on information that has been collected. It refers to the 
results of the interviews of prospective media cadres with some sources targeted about the life problems experienced by all Rabakodo brick craftsmen and the manifestation of the attention of the Village Government (especially Badan Usaha Milik Desa/BUMDesa) for their handling. Although the quality of news narratives produced by prospective village media cadres was still fairly simple and less sharp, it should be appreciated as a form of their concern to certain crucial issues that have escaped the attention of the village governments. These issues should be articulated as soon as possible to become public knowledge in Rabakodo Village. Therefore, the formation of formal village media must be implemented to be utilized by prospective media cadres as a publication tool for issues, phenomena, and/or the lives of villagers.

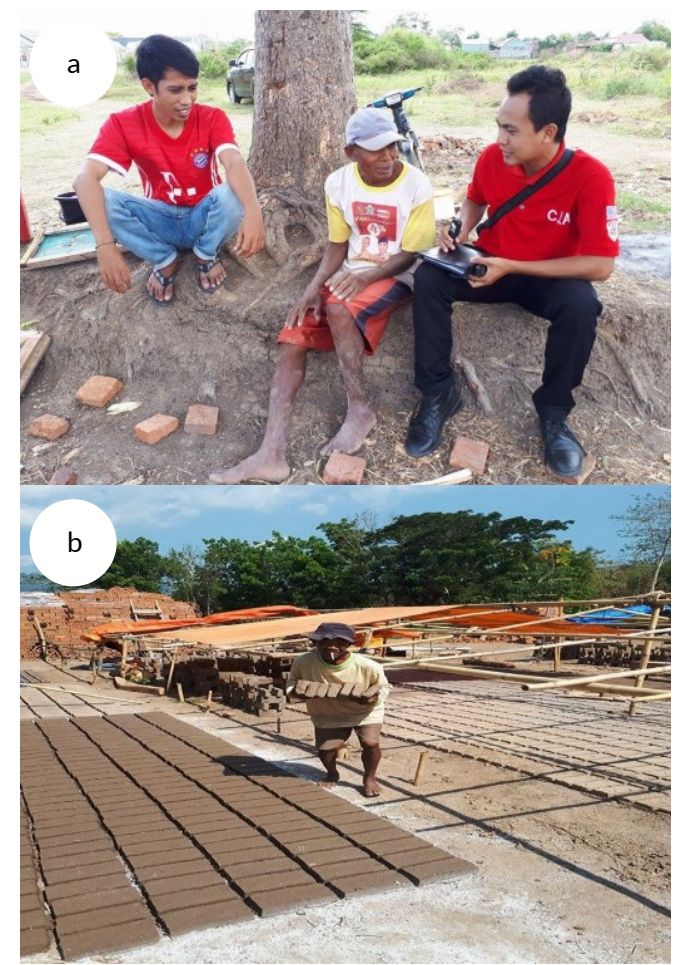

Figure 3. a) Interview of a prospective media cadre with a brick craftsman in Rabakodo Village in a follow-up practice activity; b) A brick worker's activities perpetuated by prospective media cadres in advanced practices

\subsection{Monitoring and assistance}

Monitoring and assistance were conducted in the last month of the implementation of activities, November 2019, following the submission of material and citizen journalism practices three months earlier. During this activity, prospective media cadres are encouraged to pay attention to three important aspects that are closely related to strengthening efforts for the village through the development of local communication media, namely (a) what strategic change issues will be targeted or achieved by the village media team; (b) the format or form of media chosen as a tactical and strategic measure in the village; and (c) organization: who are the personnel who manage the village media formed.

Not limited to that, monitoring and assistance also aim at discussions about the conditions that must be considered by prospective village media cadres to be used as a foothold in the citizens' media development plan in Rabakodo Village. These conditions include (a) real conditions in the village: seeing and understanding the real conditions in the village is very it is important to set targets for change to the front; (b) what is being sought: what must be done so that targets in the ideal situation can be encouraged by the village media team; and (c) output: various forms of tangible results of work that have been sought. The output target of news production, photography, and other variants can be determined from the beginning so the village media team can develop production plans from stage to stage.

\section{CONCLUSION}

Citizen journalism training is designed to inform participants about the study and formulation of problems in the village and to the ability to offer the solutions. Besides, they are also assisted in developing the ability to express opinions through various means and media such as village deliberations, written media, photography, and/or art performances. Specifically, the training was oriented towards galvanizing program participants to become a media team that can produce independently and sustainably.

Citizen journalism is seen as one of the most appropriate interventions or social engineering steps to realize social accountability in the village by strengthening the oversight role of village development management which is also inherent in youth. The potential and active participation of the youth element in overseeing the management of village development organized by the Rabakodo Village Government needs to be sharpened or strengthened through training in the use of media and communication tools.

The role of youth must be maximized in a more positive direction for village strengthening, so they can contribute significantly to improving the pattern of village development management which, undeniably, will significantly influence the acceleration of public welfare achievement. The role of supervision carried out by young people on the performance of the Rabakodo Village Government in the implementation of village development is believed to be directly proportional to the changes in the political will of the Village Government and BPD to manage development programs or activities in transparent and accountable manners.

Thus, the development of village media must be an important part of the formulation of village development programs or activities conducted by the village government, rather than being the result of 
villagers' initiative or external party intervention. It is because this vehicle or device can be utilized to empower the lives of village youth on the articulation of their ideas, assessments of the various crucial problems of the community, and how they can be taken together by the community and the village government.

\section{ACKNOWLEDGMENT}

We gratefully thank to the Directorate of Research and Community Service (Direktorat Riset dan Pengabdian Masyarakat) of KEMENRISTEK-BRIN Republik Indonesia for the financial supports through the scheme Program Kemitraan Masyarakat Stimulus (PKMS) Tahun 2019.

\section{REFERENCES}

Banda, F. (2008). Citizen Journalism \& Democracy in Africa: An Exploratory Study. Highway Africa. Grahamstown-South Africa.

Barnes, C. (2012). Citizen Journalism vs. Traditional Journalism: A Case for Collaboration. Caribbean Quarterly. 58(2): 16-27.

Hidayat, R., Hendra \& Iptidaiyah, M. (2019). The Steep Road to Institutionalizing Negotiable Governance in the Management of Village Development. Journal of Governance: Jurnal Ilmu Pemerintahan Universitas Sultan Ageng Tirtayasa. 4(1): 45-67.

Rai, N. (2016). What Is Citizen Journalism? A Critical Analysis from the Perspective of the South Asian Association for Regional Co-operation. Dissertation. Department of Communication, Marketing and Media, Aberdeen Business School, The Robert Gordon University, Scotland.

Singh, S. (2008). Citizen Journalism: Women Leaders Make Their Own News through Video and Blogging. Agenda: Empowering Women for Gender Equity. 77: 82-89.

Undang-Undang No. 6 Tahun 2014 tentang Desa. 